\title{
BARÃO DO RIO BRANCO
}

\author{
(Discurso do DR. PEDRO LESSA)
}

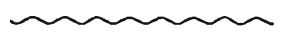

No mez de Outubro de 1907 foi a Faculdade de Direito visitada pelo eminente estadista brasileiro, Exmo. Snr Barão do Rio Branco. Em homenagem á S. Exa. o "Centro Academico Onze de Agosto" realizou uma sessão solemne á qual tambem compareceu toda a Congregação da Faculdade, sendo por essa occasião pronunciado pelo lente Dr. Pedro Lessa, o seguinte discurso:

"Exmo. Sr. Barão do Rio Branco.-Quando representante do Brasil em dous memoraveis litigios internacionaes, alcançastes a insigne victoria de fixar definitivamente as nossas fronteiras ao sul, assegurando-nos o direito sobre o territorio que os nossos adversarios pretendia in incorporar ao das Missões, e uma extensa faixa das fronteiras do norte, garantindo-nos o dominio sobre as muitas dezenas de milhares de kilometros quadrados, que vão do Araguary até o Oyapok, levantou-se em toda a vastidão deste paiz um tão espontaneo côro unisono de acclamações, e envolvęu-se o vosşo nome em um nimbo de tão 
pura e refulgente gloria que parecia impossivel a um homem, dentro do ambiente das nações contemporaneas, que tanto limitam o circulo de actividade dos estadistas, sobrelevar-se ainda mais no serviço da patria.

Foi então que, relembrando mais uma vez o patriotismo e o alto e profundo descortino de pensamento do inolvidavel Brasileiro, que foi o autor, da lei de 28 de Setembro de r87i, e enfeixando em uma só glorificação a carreira publica do pai e a do filho, sem poder affirmar qual dos dous é maior, a imprensa diaria do nosso paiz teve esta phrase eloquente para synthetizar a grandeza de ambos: na casa dos Rios Brancos as datas nacionaes frequentemente se confundem com as datas celebradas em familia.

Entretanto, operario indefeso do engrandecimento da patria, não satisfez as generosas aspirações insaciaveis do vosso intenso patriotismo esse papel de patrono que propugna a applicação das regras já consagradas do direito das gentes, e defende os limites do territorio nacional, tendo unicamente por arma de combate os mais profundos conhecimentos da historia, da geographia, do direito, da diplomacia e da politica. Ambicionando para o Brasil um scenario mais amplo e grandioso, fizestel-o apresentar-se em um congresso das nações, que elabora as proprias leis desse direito; e de eximio advogado nos pretorios internacionaes passastes a legislador benemerito da "Civitas Magna". Em verdade, foi por inspiração vossa, sob a vossa direcção e com o frequente subsidio das vossas inestimaveis instrucções, que o Brasil, representado pelo espirito fulgurante de Ruy Barbosa, tão dignamente e com tanto esplendor se esforçou pela formulaçã̉o em convenções solemnes de corolla- 
rios logicamente deduzidos de inconcussos principios cardeaes do direito internacional, principios e corollarios que os melhores publicistas eurcpeus innumeras vezes têm preconizado entre applausos universaes, e que, entretanto, as nações da Europa obstinadamente se têm recusado a reconhecer na pratica.

Mas, ha nas relações internacionaes, onde nầo são raras as mais vivas contradicções entre as lamentaveis contingencias da vida real e os ensinamentos augustos da doutrina, um acto ainda mais meritorio e glorioso do que contribuir para a formação das normas do direito: é applicar abnegadamente e em toda a sua pureza, os principios que a sciencia propaga e as regras crystalizadas nos tratados e costumes; é ter a elevação moral necessaria para abstrahir dos interesses secundarios e transitorios dos Estados e attentar sómente na utilidade geral desse vasto organismo embryonario, de que tão convencidamente nos falla Fiore, e do qual as nações são elementos integrantes, organismo que se vai formando pelo natural desenvolvimento do instincto fecundo da sociabilidade e pela incessante approximação de todas as forças individuaes e collectivas. E' o que tendes feito ininterruptamente como diréctor da politica externa do Brasil. A vossa missão tem sido umà obra continua de paz e de progresso, sem uma só cogitação egoistica, seın rivalidades nem exclusões, sem o mais leve deslise da ethica internacional. Nem a péquenez e a fraqueza da Bolivia, nem a sua éngenhosa astucia em grangear poderosos protectores, vos impediram de celebrar com ella um tratado que, reconhecendo-lhe as justas pretenções, e aproveitando-lhe economicamente; é para o Brasil uma fonte inexhaurivel de proventos. Approximastes-nos dos Estados Unidos da America do Norte, trazendo ás nossas plagas, como eloquente mịsionario da confraternização das nações 
e da solidariedade dos interesses materiaes, o mais encantador dos seus estadistas. A vossa alta cortezia para com os nossos vizinhos do sul tem reduzido ás mais comicas expressões as pequeninas rivalidades e antipathias que alguns dos filhos daquellas regiões não se fatigavam de alimentar gratuitamente contra nós. $\mathrm{E}$ ainda ha pouco representastes autorizadamente toda a America Latina, reclamando para quasi todo o continente um tratamento juridico que não quizemos acceitar exclusivamente para nós por um rasgo de heroica generosidade, que, se entre os individuos é muito rara, nas relações internacionaes nunca dantes fôra admirada na historia.

Senhores, desde os humildes e obscuros primordios da diplomacia, qual se começou a constituir entre os pequenos Estados, em que se retalhava a Italia medieval, desde o periodo negro da "diplomacia secreta», em que o historiador Philippe de Commines, o conselheiro e commensal de Luiz XI, definia os embaixadores - «uns honrados espiões», especialmente desde a época de Francisco I, o rei galante, que por justo titulo passa pelo iniciador da diplomacia como instituição europea, até ao nosso tempo, uma constante evoluçáa tem encaminhado esse instituto internacional para a realização dos fins que hoje se lhe assignam em theoria: "assegurar a paz, promover o desenvolvimento dos interesses solidarios dos Estados, garantir a liberdade, o trabalho, o commercio, a prosperidade geral, e manter a observancia do direito, contribuindo sempre para transformar a sociedade de facto dos Estados em uma sociedade regularmente crganizada» Através dos hiatos, dos recúos para o pássado, dos eclypses totaes, com que as mais condemnaveis e funestas ambições, aninhadas no labyrintho de refolhos do coração humano, têm accidentado a expansão das relações diplomaticas e 


\section{$-13-$}

a eclosão dos seus fructos, através dos mil entraves que se lhe têm opposto, não só no dominio dos factos, como no das proprias idéas, onde depois do genio, da assombrosa erudição, dos grandes principios e dos sentimentos humanitarios de um Hugo Grocio na primeira metade do seculo XVII, se nos depara já, nos ultimos dias do seculo XIX, um scientista da maior envergadura, com a responsabilidade de conselheiro e ministro da corôa em uni dos paizes mais cultos e mais conservadores da Europa, o illustre Shaefle na Austria.Hungria, a ensinar em uma obra, méramente doutrinaria, que «enfraquecer o inimigo, provocando-the scisões no proprio territorio, e rompendo-lhe as allianças, de accôrdo com as momentaneas condições do sempre instavel equilibrio internacional foi no passado, é no presente e hade ser no futuro a parte capital das funções diplomaticas"; através de todas essas cousas perturbadoras dos progressos da diplomacia, uma força ascensional, incoercivel a tem propellido para a realização do seu conceito, ou do seu ideal. Mas, se demorarmos a olhar sobre todo esse vasto periodo de formação e desenvolvimento da diplomacia, havemos de nos convencer de que, despindo-nos, por im momento, da modestia e dessa especie de temor reverencial que nos dominam quando estamos em face do extrangeiro, nos é licito affirmar com o mais justificado orgulho: nunca, em época nenhuma da historia; com tanta largueza de vistas e elevação de sentimentos, com tão justa e esclarecida comprehensão da solidariedade dos interesses dos Estados e um tão sincero afan em estreitar a amizade e a confraternização dos povos, houve um paiz que tão nobres esforços empenhasse, pela idéa e pelo facto, em pról das relações internacionaes, como o Brasil sob a dirécção do grande estadista que hoje nos honra com a sua visita. 
$\therefore$ Senhores, só o genio da antiguidade classica, só a espontanea alacridade da imaginação hellenica e o impetuoso enthusiasmo patriotico dos romanos, possuiam o segredo artistico das grandes consagrações apotheoticas com que se laureavam os cidadãos notaveis pelos talentos singulares e pelo entranhado amor á patria: A época de prosaico utilitarismo que atravessamos não sabe, utilizar-se dos moldes dessas emocionantes solemnidades, ainda mais idealizadas pela tradicção oral e escripta, que tanto impressionavam o espirito das gerações adolescentes, incutindo-lhes as mais ardentes ambições de gloria. Mas, dentro desta calma e morna atmosphera que aspiramos, toda saturada das concepções e dos calculos de uma civilisação que parece ter o seu centro de convergencia nas commodidades e satisfações do bem estar material, podemos e devemos prestar uma justa homenagem ao brasileiro que tanto nos tem engrandecido. A mocidade que me fez o interprete do seu pensamento e de seu coração, para aqui proferir estas phrases toscas, mas verdadeiras, conclamemos todos nós, os seus mestres: se quereis um modelo, que devaes esforçar-vos por imitar na vida publica, um cidadão que os jovens devem ter sempre diante dos olhos como admiravel exemplo vivo do patriotismo alliado ás mais preciosas aptidöes intellectuaes e a um infatigavel devotamento ao trabalho, aqui o tendes no Barão do Rio Branco».

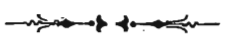

